Check for updates

\section{Data report: pore water and solid-phase trace element distribution in sediments from IODP Expedition 334 Sites U1378 and U1379 ${ }^{1}$}

\author{
C.K. Jones, ${ }^{2,3}$ N. Riedinger, ${ }^{2}$ T.W. Lyons, ${ }^{3}$ and M.E. Torres ${ }^{4}$
}

Keywords: Integrated Ocean Drilling Program, IODP, JOIDES Resolution, Expedition 334, Costa

Rica Seismogenesis Project (CRISP), Site U1378, Site U1379, geochemistry, trace metals
Contents

$\begin{array}{ll}\mathbf{1} & \text { Abstract } \\ \mathbf{1} & \text { Introduction } \\ \mathbf{2} & \text { Methods and materials } \\ \mathbf{2} & \text { Results } \\ \mathbf{5} & \text { Acknowledgments } \\ \mathbf{5} & \text { References }\end{array}$

\begin{abstract}
We report the trace element composition of solid-phase and pore water samples recovered from sediments above the framework wedge of the upper plate of the Costa Rica subduction zone at Sites U1378 and U1379 drilled during Expedition 334 of the Integrated Ocean Drilling Program. This expedition was part of the Costa Rica Seismogenesis Project (CRISP), which sampled sediments, fluids, and crustal rocks to characterize the chemical and physical properties of the eroding material in the upper plate before subduction because these sediment properties influence the seismogenic behavior of the plate interface. Molybdenum (Mo), vanadium (V), uranium $(\mathrm{U})$, arsenic (As), nickel $(\mathrm{Ni})$, and rubidium $(\mathrm{Rb})$ concentrations were measured on pore fluids and sediments using an inductively coupled plasma-mass spectrometer at the University of California, Riverside (USA). At Site U1378, pore water concentrations of the redox-sensitive elements Mo, $\mathrm{V}$, and $\mathrm{U}$, as well as As, show maximum values at or just above the contact between Lithostratigraphic Units I and II, whereas at Site U1379, these trace elements show distinct maxima in Unit II. At Site U1379, a sharp decrease in Unit III in solid-phase $\mathrm{Mo}, \mathrm{U}$, and $\mathrm{Ni}$ also occurs. In these cases, the concentration trends indicate the release of elements into the pore water in sediments dominated by clay and silty clay. The overall analyzed trace metal content in the sediments point to terrigenous material as the main input source.
\end{abstract}

\section{Introduction}

In contrast to accretionary margins, during subduction erosion a large fraction of the sediment entering the subduction zone originates from the upper plate material (Ranero and von Huene, 2000). Thus, understanding the elemental composition of the eroding material has relevance in any examination of its behavior at the plate interface and in characterizing overall elemental budgets in these margins. Integrated Ocean Drilling Program Costa Rica Seismogenesis Project (CRISP) Expedition 334 was designed to study the mechanisms involved in seismogenesis by drilling sites offshore the Osa Peninsula of Costa Rica, which is part of the active subduction erosion system along Middle America (e.g., Ranero and von Huene, 2000; Vannucchi et al., 2004; Ranero et al., 2008). At this location sampled during CRISP, the upper plate consists of a 10-12 km wide section consisting of a lower framework wedge overlain by an apron of younger sediments. In this report, we present pore water and solid-phase trace element contents of sediments from Sites U1378 and U1379 that were retrieved above the framework wedge. Characterizing the early diagenetic processes occurring in the sediments that drape the framework wedge can provide clues on diagenetic changes of the sediment prior to subduction.

Trace element concentrations can be valuable indicators of redox conditions and authigenic mineral formation in sediments. High productivity and/or reducing conditions in the water column can lead to high burial rates of these redox-sensitive trace elements, but they can also be lost during diagenesis or postdepositional reoxygenation (e.g., Emerson and Huested, 1991; Crusius et al., 1996; McManus et al., 2006). Similar to enrichments under reducing water columns, molybdenum (Mo), vanadium (V), and uranium (U) can also accumulate in reducing sediments, often due to association with authigenic sulfide formation, thus recording changes in the redox conditions (e.g., Calvert and Pedersen, 1993; Tribovillard et al., 2008; Lyons et al., 2009; Morford et al., 2009; Scott and Lyons, 2012; Hardisty et al., 2018). Many trace elements adsorb to or are associated with iron (Fe) and manganese (Mn) (oxyhydr)oxides (e.g., Morford and Emerson, 1999). During diagenesis, $\mathrm{Fe}$ and $\mathrm{Mn}$ (oxyhydr)oxides can be cycled under reducing conditions related to microbial metabolic processes. As these oxides dissociate, adsorbed trace elements, such as Mo, V, and $\mathrm{U}$, are released into the pore water. Under sulfidic conditions, Fe and Mn can precipitate as sulfide minerals (e.g., Goldhaber and Kaplan, 1974; Jørgensen, 1977, 1982;

\footnotetext{
Jones, C.K., Riedinger, N., Lyons, T.W., and Torres M.E., 2021. Data report: pore water and solid-phase trace element distribution in sediments from IODP Expedition 334 Sites U1378 and U1379. In Vannucchi, P., Ujiie, K., Stroncik, N., Malinverno, A., and the Expedition 334 Scientists, Proceedings of the Integrated Ocean Drilling Program, 334: Tokyo (Integrated Ocean Drilling Program Management International, Inc.). doi:10.2204/iodp.proc.334.204.2021

2 Boone Pickens School of Geology, Oklahoma State University, USA.

${ }^{3}$ Department of Earth and Planetary Sciences, University of California, Riverside, USA. Correspondence author: cjone095@ucr.edu

${ }^{4}$ College of Earth, Ocean, and Atmospheric Science, Oregon State University, USA.

MS 334-204: Received 2 February 2021 • Accepted 26 May 2021 • Published 20 October 2021

This work is distributed under the Creative Commons Attribution 4.0 International (CC BY 4.0) license. (c) BY
} 
Berner, 1984; Thamdrup et al., 1994), and certain trace elements, such as arsenic (As) or nickel $(\mathrm{Ni})$, precipitate in sulfide minerals (e.g., pyrite) or in the reducing sediments that host the pyrite (e.g., Morse and Arakaki, 1993; Borchers et al., 2005; Middelburg and Levin, 2009; Gregory et al., 2019)-resulting in authigenic enrichment fronts (Riedinger et al., 2014; Little et al., 2015). Contrary to Mo, V, and U, which are primarily associated with Fe and Mn oxides, As and Ni delivery to the sediment is influenced to a greater degree by organic matter, with $\mathrm{Ni}$ having the strongest association relatively (Borchers et al., 2005). Trace elements can also be sourced from volcanogenic input or vent activity along the Costa Rica margin (Boström and Fisher, 1971; Han et al., 2004). Weathering of reactive silicates and associated formation of authigenic minerals can alter the element distribution in sediments and pore water (e.g., Abercrombie et al., 1994; Aloisi et al., 2004; Wallmann et al., 2008; Torres et al., 2020). Because of its similarity to other alkali metals and their association with clay minerals, we report rubidium $(\mathrm{Rb})$ pore water data alongside Mo, V, U, As, and Ni to aid in identifying authigenic clay formation and alteration and related trace element cycling (Welby, 1958; Biscaye and Dasch, 1971).

\section{Study sites}

Full descriptions of the two sites targeted for trace element analyses are provided in the Site U1378 and Site U1379 chapters (Expedition 334 Scientists, 2012b, 2012c). Site U1378 sampled the overlying apron of about $564 \mathrm{~m}$ of slope sediments above the upper plate framework wedge. Sediment here accumulated at average rates of $516 \mathrm{~m} / \mathrm{My}$ from 0 to 237 meters below seafloor (mbsf) and $236 \mathrm{~m} / \mathrm{My}$ from 237 to $524 \mathrm{mbsf}$. The sediments, which can be divided into two lithostratigraphic units, consist mostly of silty clay to clay with widely interspersed centimeter-scale sandy layers. Lithostratigraphic Unit I consists of approximately $128 \mathrm{~m}$ of soft, dark greenish gray terrigenous silty clay. Unit II (128-564 mbsf) consists of massive, well consolidated, olive-green terrigenous clayey silt(stone) and silty clay(stone). Throughout the core, 82 tephra layers were identified by shipboard sedimentologists. Total organic carbon (TOC) contents generally decrease downhole from approximately 2 to $0.75 \mathrm{wt} \%$ (see the Site U1378 chapter [Expedition 334 Scientists, 2012b]).

Site U1379 is the shallowest site drilled during Expedition 334. Pore water data reported here only reflect the upper $200 \mathrm{~m}$ of sediments retrieved because of sample availability; solid-phase analyses were conducted throughout the drilled sediment column. The sediments from Site U1379 consist predominantly of silty clay to clay alternating with widely interspersed decimeter-scale sandy layers and are divided into five lithostratigraphic units as described in the Site U1379 chapter (Expedition 334 Scientists, 2012c). Lithostratigraphic Unit I consists of the relatively thin uppermost sediments and is characterized by medium- to coarse-grained sand with abundant shell fragments. Unit II ( $\sim 650 \mathrm{~m}$ thick) is mainly massive, well consolidated olive-green clayey silt(stone) and silty clay(stone) with minor layers of unlithified tephra. Unit III ( 229 m thick) sediments are olive-green silty sand and sandstone with decimeter thick fining- and coarsening-upward sequences; scattered tephra layers are reported in the upper section of this unit. Unit IV is only $\sim 2 \mathrm{~m}$ thick and consists of carbonate-cemented, lithic pebble-sized clasts and thick-walled shell shards. Unit V consists of $\sim 67 \mathrm{~m}$ of fine sandy matrix-supported breccia with clasts of limestone, basalt, and mudstone. Basalt layers are interspersed in the upper section, whereas a sequence of clayey silt appears in the lower part of this unit. The uppermost $\sim 566 \mathrm{~m}$ and between $\sim 566$ and 722 mbsf were deposited with sedimentation rates of $\sim 1230$ and $100 \mathrm{~m} / \mathrm{My}$, respectively (see the Site U1379 chapter [Expedition 334 Scientists, 2012c]). TOC contents scatter strongly throughout the sediment column with values ranging from 2.45 to $0.11 \mathrm{wt} \%$ (see the Site U1379 chapter [Expedition 334 Scientists, 2012c]).

In contrast to Site U1378, Site U1379 is characterized by distinct layers of authigenic carbonates as thick as $11 \mathrm{~m}$ in Unit II (see the Site U1379 chapter [Vannucchi et al., 2012c]; Riedinger et al., 2019). The formation of these layers is related to the tectonic history in this region. Episodes of burial and uplift (e.g., Vannucchi et al., 2013) led to changes in methane flux and subsequent shifting of the sulfate-methane transition (SMT) associated with authigenic carbonate precipitation concurrent with iron sulfide formation (Riedinger et al., 2019).

\section{Methods and materials}

Pore water was collected from sediment samples taken from whole-round cores cut on deck and immediately taken to the laboratory for processing. Sediment samples were cleaned to remove outer layer contamination, and pore water was collected using a titanium pore water press modified after the stainless-steel squeezer of Manheim and Sayles (1974). The retrieved pore water was filtered through $0.2 \mu \mathrm{m}$ polysulfone disposable filters into attached, precleaned syringes. Sample aliquots for trace element analysis were acidified with $20 \mu \mathrm{L} / \mathrm{mL}$ concentrated $\mathrm{HNO}_{3}$ (trace metal grade) and stored cool at $+4^{\circ} \mathrm{C}$. Solid-phase samples were immediately collected and stored frozen at $-20^{\circ} \mathrm{C}$ for further analyses. For details of the sampling methods, see the Methods chapter (Expedition 334 Scientists, 2012a).

Element concentrations in the pore water were determined on acidified splits following 25 -fold dilution with trace metal grade $2 \%$ $\mathrm{HNO}_{3}$. Standards were prepared to match the salt matrix with trace metal grade, ultrapure $\mathrm{NaCl}$. All samples were measured on an inductively coupled plasma-mass spectrometer (ICP-MS; Agilent 7500ce) at the University of California, Riverside (USA). For quality control, an in-house seawater standard with an average seawater composition was measured during each run, and all data acquired are within $5 \%$ analytical error.

Solid-phase samples of about $50 \mathrm{mg}$ dried and homogenized material were digested using $\mathrm{HNO}_{3}, \mathrm{HCl}$, and $\mathrm{HF}$ at $\sim 180^{\circ} \mathrm{C}$. The acids were evaporated, and the digested sample was dissolved in $2 \%$ $\mathrm{HNO}_{3}$ (for detailed methodology, see Riedinger et al., 2014). Standard reference material (United States Geological Survey SDO-1) splits were digested and analyzed with each sample batch for quality control. All samples were measured on the Agilent 7500ce ICP-MS at the University of California, Riverside following 50-fold dilution with $2 \% \mathrm{HNO}_{3}$. The analytical error was better than $5 \%$.

The cored intervals were measured according to the core depth below seafloor, Method A (CSF-A), depth scale (see the Methods chapter [Expedition 334 Scientists, 2012a]) and reported in meters below seafloor.

\section{Results}

Pore water concentration data are listed in Tables T1 and T2, and solid-phase values are provided in Tables T3 and T4. Downcore distributions are illustrated in Figures F1 and F2. 


\section{Pore water concentrations}

\section{Site U1378}

Concentrations of the redox-sensitive elements As, Mo, V, and $\mathrm{U}$ exhibit similar profiles in the uppermost $300 \mathrm{~m}$ (Figure F1A), which roughly corresponds to the Lithostratigraphic Unit I/II boundary. The profiles show two prominent concentration peaks in Mo, V, and U and three peaks in As. At $\sim 70-100 \mathrm{mbsf}, \mathrm{Mo}, \mathrm{V}, \mathrm{U}$, and As concentrations are highly elevated (2432, 894, 98.7, and 882 $\mathrm{nM}$, respectively) compared to average seawater values of 105,27 , 14, and $25 \mathrm{nM}$, respectively (Turekian, 1968; Bruland and Lohan, 2006). The second maxima occurs between $\sim 108$ and $136 \mathrm{mbsf}$,

Table T1. Pore water element data for sediments, Site U1378. Download table in CSV format.

Table T2. Pore water element data for sediments, Site U1379. Download table in CSV format.

Table T3. Solid-phase element data for sediments, Site U1378. Download table in CSV format.

Table T4. Solid-phase element data for sediments, Site U1379. Download table in CSV format. with $\mathrm{V}$ reaching $855 \mathrm{nM}$ at $\sim 108 \mathrm{mbsf}$, Mo and U reaching 2051 and $21.7 \mathrm{nM}$, respectively, at $\sim 118 \mathrm{mbsf}$, and As reaching $507 \mathrm{nM}$ at $\sim 136$ mbsf. The similarities in the profiles are most likely due to the similar responses that $\mathrm{V}, \mathrm{Mo}$, and $\mathrm{U}$ have to changing redox conditions in the sediments, particularly as related to their cycling with Fe and Mn minerals in these fine-grained deposits. Such behavior has been documented previously at this site (Torres et al., 2014; Riedinger et al., 2019).

As has a smaller third peak, reaching $391 \mathrm{nM}$ at $\sim 23$ mbsf just below the SMT (Figure F1A), which occurs at 13 mbsf at this site (see the Site U1378 chapter [Expedition 334 Scientists, 2012b]; Riedinger et al., 2019). The broad maxima of up to $880 \mathrm{nM}$ at 150 mbsf and up to $570 \mathrm{nM}$ below $300 \mathrm{mbsf}$ may be linked to increased iron sulfide formation in these layers (Riedinger et al., 2019). Below Unit I, V and U concentrations decrease with increasing depth; Mo concentrations, however, gradually increase toward the bottom of the sampled intervals (Figure F1A).

At $\sim 7 \mathrm{mbsf}$, Ni reaches a maximum of $540 \mathrm{nM}$, and it ranges between $\sim 50$ and $\sim 250 \mathrm{nM}$ over the remaining sediment column. These concentrations are elevated compared to the average seawater value of $12 \mathrm{nM}$ (Bruland and Lohan, 2006). Rb concentrations show an overall decreasing trend from seawater concentrations of approximately $1400 \mathrm{nM}$ to the bottom of the sampled interval, suggestive of Rb uptake during authigenic clay formation (Dasch, 1969;

Figure F1. Downhole pore water concentration profiles. Lithostratigraphic columns and ages taken from Riedinger et al. (2019; modified after Expedition 334 Scientists, 2012b, with tephra ages [*] from Schindlbeck et al., 2016). Red arrows = average seawater values (after Turekian, 1968; Bruland and Lohan, 2006), black dashed line $=$ lithostratigraphic unit boundary, red dashed line = sulfate-methane transition. A. Hole U1378B. B. Hole U1379C.
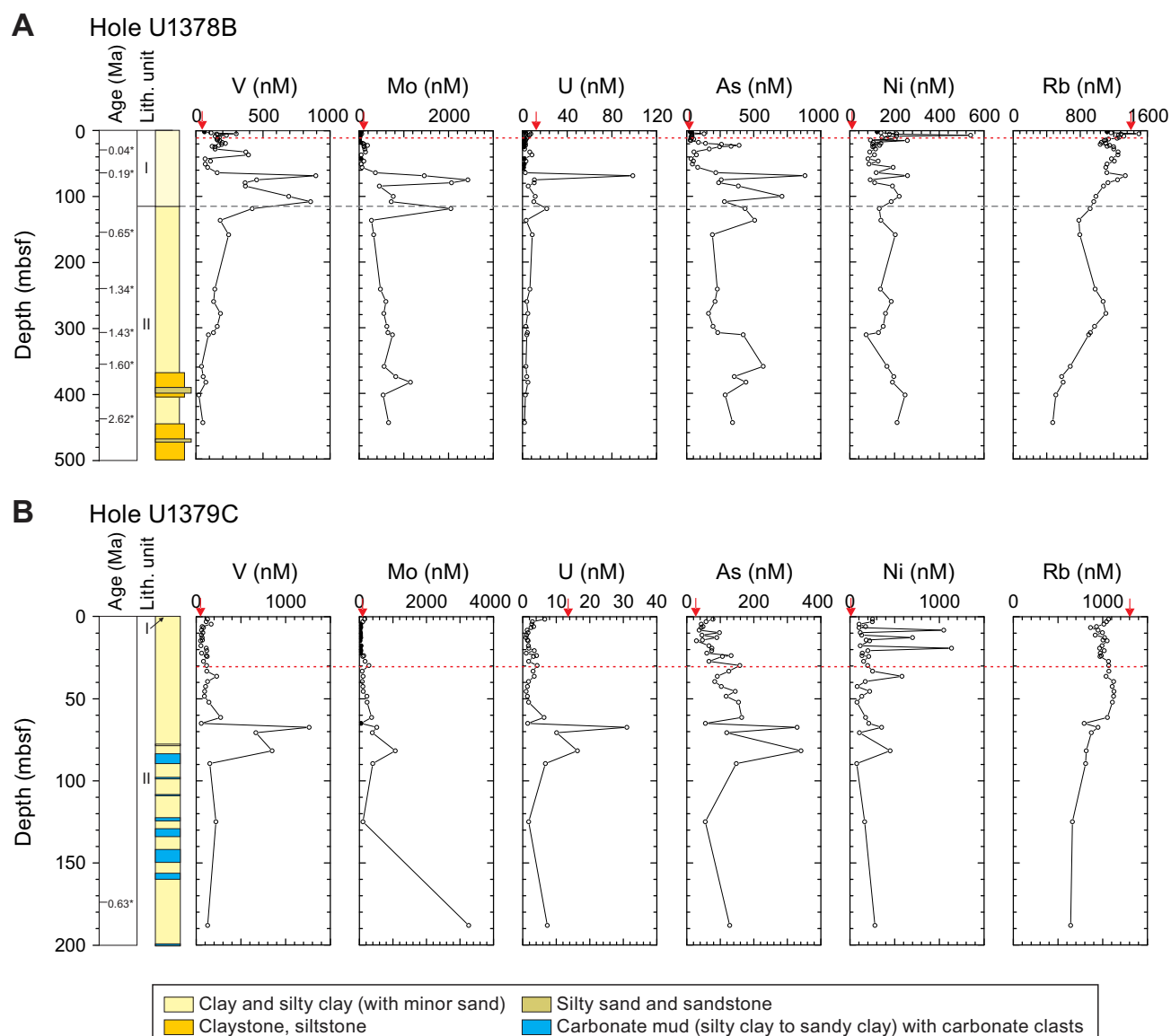
$\square$ Carbonate mud (silty clay to sandy clay) with carbonate clasts 
Figure F2. Downhole solid-phase trace metal content profiles (squares) and element to aluminum ratios (gray lines). Lithostratigraphic columns and ages taken from Riedinger et al. (2019; modified after Expedition 334 Scientists, 2012b, with tephra ages [*] from Schindlbeck et al., 2016). Black dashed line = lithostratigraphic unit boundary, red dashed line = sulfate-methane transition, red arrows indicate average crustal values (after Taylor and McLennan, 1995). A. Hole U1378B. B. Hole U1379C.
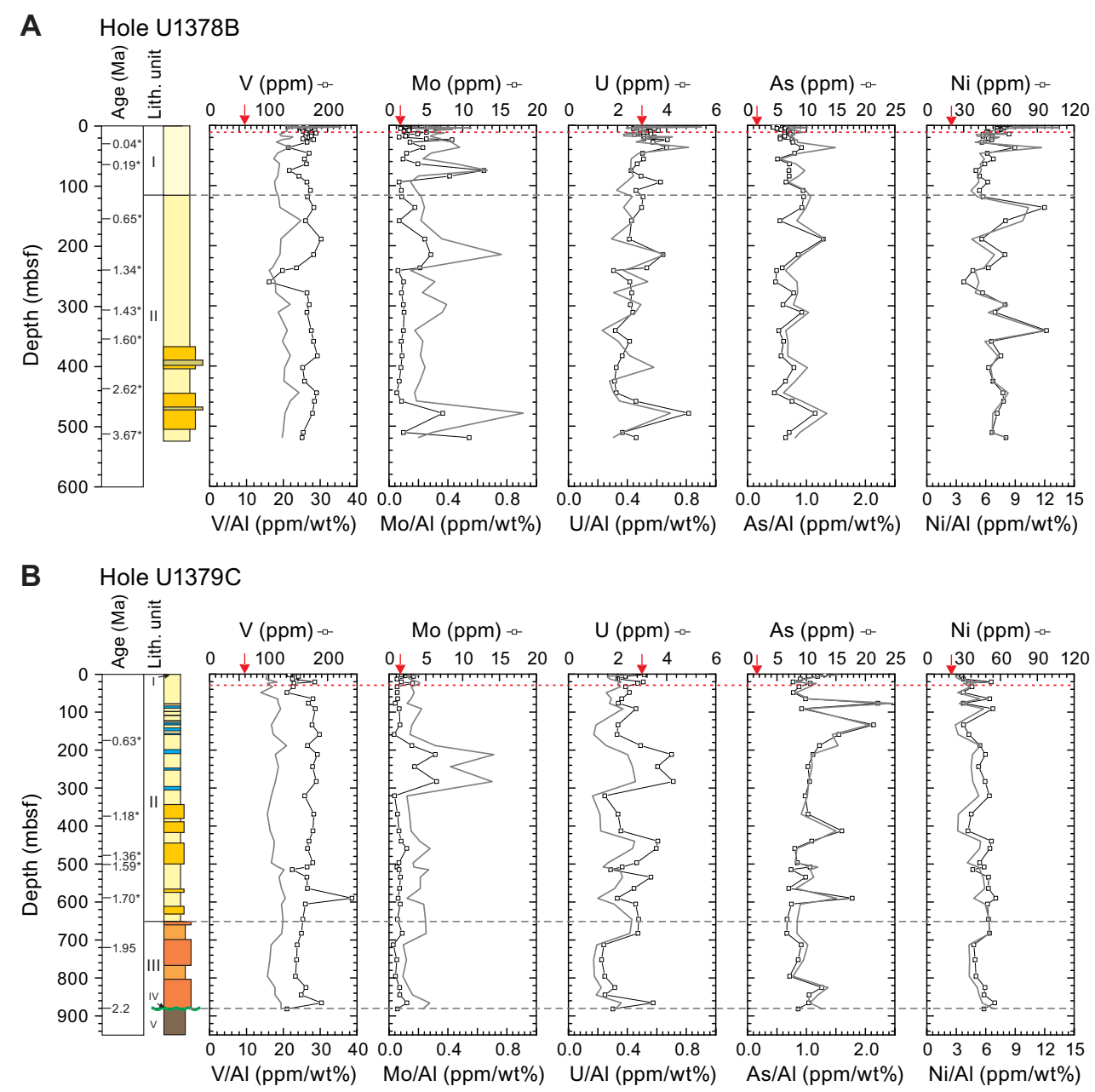

\begin{tabular}{|l|}
$\square$ Clay and silty clay (with minor sand) \\
$\square$ Claystone, siltstone \\
$\square$ Silty claystone, fine sandstone, matrix-supported breccia \\
$\square$ Carbonate mud (silty clay to sandy clay) with carbonate clasts \\
$\square$ Fine sandstone
\end{tabular}

Biscaye and Dasch, 1971; Bruland and Lohan, 2006). At 70 mbsf, $\mathrm{Rb}$ slightly increases to $1338 \mathrm{nM}$ before it continues to decrease to $\sim 800 \mathrm{nM}$ at $140 \mathrm{mbsf}$. Rb concentrations then increase to $1106 \mathrm{nM}$ at $280 \mathrm{mbsf}$ before decreasing with depth.

\section{Site U1379}

Pore water profiles for the redox-sensitive elements measured in the uppermost $200 \mathrm{~m}$ at Site U1379 (Figure F1B) show trends similar to those observed at Site U1378. Although the Mn profile (Torres et al., 2014) does not show a good correlation with the Mo, V, and $U$ profiles, their distribution is indicative of $\mathrm{Mn}$ (and Fe) oxide dissolution, which can cause the release of associated trace elements (e.g., Shimmield and Price, 1986). Similar to the profiles from Site U1378, the clearest features are two peaks in Mo, V, U, and As concentrations at $\sim 67$ and $82 \mathrm{mbsf}$, although they are less distinct than those at Site U1378. For the shallower of the two maxima, Mo, $\mathrm{V}, \mathrm{U}$, and As concentrations reach 518, 1263, 31.1, and $329 \mathrm{nM}$, respectively; for the deeper maxima, concentrations reach 1070, 849,
16.3, and $341 \mathrm{nM}$, respectively. These trace element maxima are all observed in Unit II deposits. The similarities in the Mo, U, and V concentration profiles are consistent with Fe and Mn oxide cycling in the fine-grained deposits (Riedinger et al., 2019). Pore water As concentrations do not show an upper peak at the SMT, which is located at around 30-40 mbsf (Figure F1B), but they gradually increase to a maximum of $341 \mathrm{nM}$ at $\sim 82$ mbsf before decreasing downhole. Interestingly, the deepest pore water samples measured from Site U1379 show Mo concentrations $>3 \mu \mathrm{M}$. This Mo maximum corresponds with a solid-phase Mo enrichment (Figure F2B), most likely pointing to an ongoing release of Mo into the pore water in these deeper sediments.

$\mathrm{Ni}$ concentrations reach their maximum value of $1136 \mathrm{nM}$ in the uppermost $20 \mathrm{~m}$ and remain below $600 \mathrm{nM}$ downhole but with slight scatter. $\mathrm{Rb}$ concentrations remain relatively constant in the uppermost $60 \mathrm{~m}$ except for a slight decrease in the uppermost $10 \mathrm{~m}$ (Figure F1B). Deeper than $60 \mathrm{mbsf}, \mathrm{Rb}$ concentrations decrease to 
$641 \mathrm{nM}$, indicating uptake during authigenic clay formation similar to that observed at Site U1378.

\section{Solid-phase content}

\section{Site U1378}

Solid-phase contents of $\mathrm{V}$ remain relatively constant between 165 and $180 \mathrm{ppm}$ compared to the average upper crustal value of 60 ppm (after Taylor and McLennan, 1995), but two distinct minima occur at 260 and 402 mbsf where contents drop to 101 and 158 ppm, respectively. Although both minima are in Unit II, the lower one occurs in a clay/silty clay layer between two fine sandstones. Mo, $U$, and As each show three distinct maxima at $\sim 36,214$, and 478 mbsf with contents of 3.85, 7.04, and $7.77 \mathrm{ppm}$, respectively, for Mo; 5.00, 6.06, and $5.90 \mathrm{ppm}$, respectively, for $\mathrm{U}$; and 9.15, 12.9, and $11.5 \mathrm{ppm}$, respectively, for As. $\mathrm{U}$ and Mo both show maxima at the bottom of Unit I and remain relatively constant between other maxima. The overall low solid-phase contents of Mo, U, and As and their ratios with $\mathrm{Al}$ (Figure F2B) suggest that terrigenous input is the main source of the trace elements, with contents near average crustal values of 1.5, 2.8, and $1.5 \mathrm{ppm}$, respectively (after Taylor and McLennan, 1995). This does not, however, explain the observed maxima. The similar behaviors of Mo, $\mathrm{U}$, and As are likely due to their association with Fe and Mn (oxyhydr)oxides and sulfide minerals or the formation and alteration of iron-rich clay minerals, which has been described for sediments along the Costa Rica margin (Charpentier et al., 2011).

$\mathrm{Ni}$ contents are elevated relative to upper continental values of $20 \mathrm{ppm}$ (after Taylor and McLennan, 1995) and have three maxima of 71.7, 95.9, and $97.5 \mathrm{ppm}$ at $\sim 36,136$, and $341 \mathrm{mbsf}$, respectively. The second maxima at $\sim 136$ mbsf aligns with a change in lithology from terrigenous silty clay to terrigenous clayey silt(stone) and silty clay(stone) between Units I and II.

\section{Site U1379}

$\mathrm{V}$ contents are relatively low in the uppermost $50 \mathrm{~m}$ with the exception of one peak of $178 \mathrm{ppm}$ at $\sim 20 \mathrm{mbsf}$. Throughout the remainder of the core, the contents remain relatively stable other than a peak of $241 \mathrm{ppm}$ at $\sim 590 \mathrm{mbsf}$. These values are high compared to average continental crust (Taylor and McLennan, 1995; Rudnick and Gao, 2003).

Mo and $U$ contents exhibit similar behavior throughout the core, although Mo contents tend to be more constant between peaks. Elevated contents of approximately 7 and $4 \mathrm{ppm}$ for Mo and $\mathrm{U}$, respectively, occur between $\sim 210$ and 280 mbsf. The observed increases coincide with an increase in pyrite (Riedinger et al., 2019), suggesting co-precipitation of these metals during authigenic iron sulfide formation. Another peak occurs at $~ 450 \mathrm{mbsf}$, where Mo reaches $2.66 \mathrm{ppm}$ and $U$ reaches $4.32 \mathrm{ppm}$. Farther downcore, Mo remains roughly constant, but $U$ shows two more peaks of 3.42 and $3.52 \mathrm{ppm}$ at 646 and $866 \mathrm{mbsf}$, respectively. The overall similar behaviors for Mo and $U$ are likely a result of their mutual associations with Fe and Mn oxides.

As reaches its highest content of $22.1 \mathrm{ppm}$ at $\sim 77 \mathrm{mbsf}$. Downcore, it generally remains between 8 and $12 \mathrm{ppm}$ other than several small peaks. One peak at $\sim 413$ mbsf corresponds with a peak in U, which could imply that As is also being cycled with Fe and Mn oxides in the sediments.

$\mathrm{Ni}$ contents fluctuate between $\sim 27$ and $\sim 53 \mathrm{ppm}$ in the uppermost $200 \mathrm{~m}$. Aside from a decrease between 300 and $400 \mathrm{mbsf}, \mathrm{Ni}$ contents remain relatively constant at around $50 \mathrm{ppm}$ throughout the remainder of Unit II. Near the top of Unit III, however, a sharp decrease to $37.5 \mathrm{ppm}$ occurs at $\sim 515 \mathrm{mbsf}$ before values rise back to $\sim 50 \mathrm{ppm}$ downcore. This sharp decrease is also seen in the Mo and $\mathrm{U}$ profiles, indicating that these three trace metals are being released together, likely during $\mathrm{Fe}$ and $\mathrm{Mn}$ oxide dissolution, and are being consumed from the pore water during the formation of authigenic sulfide minerals.

\section{Acknowledgments}

This research used samples and data provided by the Integrated Ocean Drilling Program (IODP), which was sponsored by the US National Science Foundation and participating countries and universities under management of IODP Management International, Inc. We are indebted to the captain, crew, drilling personnel, and scientific party of IODP Expedition 334. For assistance in the laboratory, we are grateful to S. Bates and E. Goldbaum. This research was funded by a US Science Support Program (USSSP) postcruise research Award T334B11 to the author.

\section{References}

Abercrombie, H.J., Hutcheon, I.E., Bloch, J.D., and Caritat, P.D., 1994. Silica activity and the smectite-illite reaction. Geology, 22(6):539-542.

https://doi.org/10.1130/0091-

7613(1994)022<0539:SAATSI $>2.3 . \mathrm{CO} ; 2$

Aloisi, G., Wallmann, K., Drews, M., and Bohrmann, G., 2004. Evidence for the submarine weathering of silicate minerals in Black Sea sediments: possible implications for the marine Li and B cycles. Geochemistry, Geophysics, Geosystems, 5(4):Q04007. https://doi.org/10.1029/2003GC000639

Berner, R.A., 1984. Sedimentary pyrite formation: an update. Geochimica et Cosmochimica Acta, 48(4):605-615. https://doi.org/10.1016/0016-7037(84)90089-9

Biscaye, P.E., and Dasch, E.J., 1971. The rubidium, strontium, strontium-isotope system in deep-sea sediments: Argentine Basin. Journal of Geophysical Research, 76(21):5087-5096. https://doi.org/10.1029/JC076i021p05087

Borchers, S.L., Schnetger, B., Böning, P., and Brumsack, H.-J., 2005. Geochemical signatures of the Namibian diatom belt: Perennial upwelling and intermittent anoxia. Geochemistry, Geophysics, Geosystems, 6(6):Q06006. https://doi.org/10.1029/2004GC000886

Boström, K., and Fisher, D.E., 1971. Volcanogenic uranium, vanadium and iron in Indian Ocean sediments. Earth and Planetary Science Letters, 11(1):95-98. https://doi.org/10.1016/0012-821X(71)90148-8

Bruland, K.W., and Lohan, M.C., 2006. Controls of trace metals in seawater. In Elderfield, H. (Ed.), Treatise on Geochemistry (Volume 6): The Oceans and Marine Geochemistry: Amsterdam (Elsevier), 23-47.

Calvert, S.E., and Pedersen, T.F., 1993. Geochemistry of recent oxic and anoxic marine sediments: implications for the geological record. Marine Geology, 113(1-2):67-88. https://doi.org/10.1016/0025-3227(93)90150-T

Charpentier, D., Buatier, M.D., Jacquot, E., Gaudin, A., and Wheat, C.G., 2011. Conditions and mechanism for the formation of iron-rich Montmorillonite in deep sea sediments (Costa Rica margin): coupling high resolution mineralogical characterization and geochemical modeling. Geochimica et Cosmochimica Acta, 75(6):1397-1410. https://doi.org/10.1016/j.gca.2010.11.026

Crusius, J., Calvert, S., Pedersen, T., and Sage, D., 1996. Rhenium and molybdenum enrichments in sediments as indicators of oxic, suboxic and sulfidic conditions of deposition. Earth and Planetary Science Letters, 145(1-4):65-78. https://doi.org/10.1016/S0012-821X(96)00204-X

Dasch, E.J., 1969. Strontium isotopes in weathering profiles, deep-sea sediments, and sedimentary rocks. Geochimica et Cosmochimica Acta, 33(12):1521-1552. https://doi.org/10.1016/0016-7037(69)90153-7 
Emerson, S.R., and Huested, S.S., 1991. Ocean anoxia and the concentrations of molybdenum and vanadium in seawater. Marine Chemistry, 34(34):177-196. https://doi.org/10.1016/0304-4203(91)90002-E

Expedition 334 Scientists, 2012a. Methods. In Vannucchi, P., Ujiie, K., Stroncik, N., and the Expedition 334 Scientists, Proceedings of the Integrated Ocean Drilling Program, 334: Tokyo (Integrated Ocean Drilling Program Management International, Inc.). https://doi.org/10.2204/iodp.proc.334.101.2012

Expedition 334 Scientists, 2012b. Site U1378. In Vannucchi, P., Ujiie, K., Stroncik, N., and the Expedition 334 Scientists, Proceedings of the Integrated Ocean Drilling Program, 334: Tokyo (Integrated Ocean Drilling Program Management International, Inc.). https://doi.org/10.2204/iodp.proc.334.103.2012

Expedition 334 Scientists, 2012c. Site U1379. In Vannucchi, P., Ujiie, K., Stroncik, N., and the Expedition 334 Scientists, Proceedings of the Integrated Ocean Drilling Program, 334: Tokyo (Integrated Ocean Drilling Program Management International, Inc.). https://doi.org/10.2204/iodp.proc.334.104.2012

Goldhaber, M.B., and Kaplan, I.R., 1974. The sulfur cycle. In Goldberg, E.D. (Ed.), The Sea (Volume 5): Marine Chemistry: New York (Wiley), 569655.

Gregory, D., Mukherjee, I., Olson, S.L., Large, R.R., Danyushevsky, L.V., Stepanov, A.S., Avila, J.N., et al., 2019. The formation mechanisms of sedimentary pyrite nodules determined by trace element and sulfur isotope microanalysis. Geochimica et Cosmochimica Acta, 259:53-68. https://doi.org/10.1016/j.gca.2019.05.035

Han, X., Suess, E., Sahling, H., and Wallmann, K., 2004. Fluid venting activity on the Costa Rica margin: new results from authigenic carbonates. International Journal of Earth Sciences, 93(4):596-611. https://doi.org/10.1007/s00531-004-0402-y

Hardisty, D.S., Lyons, T.W., Riedinger, N., Isson, T.T., Owens, J.D., Aller, R.C., Rye, D.M., et al., 2018. An evaluation of sedimentary molybdenum and iron as proxies for pore fluid paleoredox conditions. American Journal of Science, 318(5):527-556. https://doi.org/10.2475/05.2018.04

Jørgensen, B.B., 1977. The sulfur cycle of a coastal marine sediment (Limfjorden, Denmark). Limnology and Oceanography, 22(5):814-832. https://doi.org/10.4319/lo.1977.22.5.0814

Jørgensen, B.B., 1982. Mineralization of organic matter in the sea bed-the role of sulphate reduction. Nature, 296(5858):643-645. https://doi.org/10.1038/296643a0

Little, S., Vance, D., Lyons, T.W., and McManus, J., 2015. Controls on trace metal authigenic enrichment in reducing sediments: insights from modern oxygen-deficient settings. American Journal of Science, 315(2):77119. https://doi.org/10.2475/02.2015.01

Lyons, T.W., Anbar, A.D., Severmann, S., Scott, C., and Gill, B.C., 2009. Tracking euxinia in the ancient ocean: a multiproxy perspective and proterozoic case study. Annual Review of Earth and Planetary Sciences, 37(1):507-534. https://doi.org/10.1146/annurev.earth.36.031207.124233

Manheim, F.T., and Sayles, F.L., 1974. Composition and origin of interstitial waters of marine sediments, based on deep sea drill cores. In Goldberg, E.D. (Ed.), The Sea (Volume 5): Marine Chemistry: The Sedimentary Cycle: New York (Wiley), 527-568. http://pubs.er.usgs.gov/publication/70207491

McManus, J., Berelson, W.M., Severmann, S., Poulson, R.L., Hammond, D.E., Klinkhammer, G.P., and Holm, C., 2006. Molybdenum and uranium geochemistry in continental margin sediments: paleoproxy potential. Geochimica et Cosmochimica Acta, 70(18):4643-4662. https://doi.org/10.1016/j.gca.2006.06.1564

Middelburg, J.J., and Levin, L.A., 2009. Coastal hypoxia and sediment biogeochemistry. Biogeosciences, 6(7):1273-1293. https://doi.org/10.5194/bg-6-1273-2009

Morford, J.L., and Emerson, S., 1999. The geochemistry of redox sensitive trace metals in sediments. Geochimica et Cosmochimica Acta, 63(11):1735-1750. https://doi.org/10.1016/S0016-7037(99)00126-X

Morford, J.L., Martin, W.R., François, R., and Carney, C.M., 2009. A model for uranium, rhenium, and molybdenum diagenesis in marine sediments based on results from coastal locations. Geochimica et Cosmochimica Acta, 73(10):2938-2960. https://doi.org/10.1016/j.gca.2009.02.029

Morse, J.W., and Arakaki, T., 1993. Adsorption and coprecipitation of divalent metals with mackinawite (FeS). Geochimica et Cosmochimica Acta, 57(15):3635-3640. https://doi.org/10.1016/0016-7037(93)90145-M

Ranero, C.R., Grevemeyer, I., Sahling, H., Barckhausen, U., Hensen, C., Wallmann, K., Weinrebe, W., Vannucchi, P., von Huene, R., and McIntosh, K., 2008. Hydrogeological system of erosional convergent margins and its influence on tectonics and interplate seismogenesis. Geochemistry, Geophysics, Geosystems, 9(3):Q03S04. https://doi.org/10.1029/2007GC001679

Ranero, C.R., and von Huene, R., 2000. Subduction erosion along the Middle America convergent margin. Nature, 404(6779):748-752. https://doi.org/10.1038/35008046

Riedinger, N., Formolo, M.J., Lyons, T.W., Henkel, S., Beck, A., and Kasten, S., 2014. An inorganic geochemical argument for coupled anaerobic oxidation of methane and iron reduction in marine sediments. Geobiology, 12(2):172-181. https://doi.org/10.1111/gbi.12077

Riedinger, N., Torres, M.E., Screaton, E., Solomon, E.A., Kutterolf, S., Schindlbeck-Belo, J., Formolo, M.J., Lyons, T.W., and Vannucchi, P., 2019. Interplay of subduction tectonics, sedimentation, and carbon cycling. Geochemistry, Geophysics, Geosystems, 20(11):4939-4955. https://doi.org/10.1029/2019GC008613

Rudnick, R.L., and Gao, S., 2003. Composition of the continental crust. Treatise on Geochemistry, 3:1-64. https://doi.org/10.1016/B0-08-043751-6/03016-4

Schindlbeck, J.C., Kutterolf, S., Freundt, A., Straub, S.M., Vannucchi, P., and Alvarado, G.E., 2016. Late Cenozoic tephrostratigraphy offshore the southern Central American Volcanic Arc: 2. Implications for magma production rates and subduction erosion. Geochemistry, Geophysics, Geosystems, 17(11):4585-4604.

https://doi.org/10.1002/2016GC006504

Scott, C., and Lyons, T.W., 2012. Contrasting molybdenum cycling and isotopic properties in euxinic versus non-euxinic sediments and sedimentary rocks: refining the paleoproxies. Chemical Geology, 324-325:19-27. https://doi.org/10.1016/j.chemgeo.2012.05.012

Shimmield, G.B., and Price, N.B., 1986. The behaviour of molybdenum and manganese during early sediment diagenesis - offshore Baja California, Mexico. Marine Chemistry, 19(3):261-280. https://doi.org/10.1016/0304-4203(86)90027-7

Taylor, S.R., and McLennan, S.M., 1995. The geochemical evolution of the continental crust. Reviews of Geophysics, 33(2):241-265. https://doi.org/10.1029/95RG00262

Thamdrup, B., Fossing, H., and Jørgensen, B.B., 1994. Manganese, iron and sulfur cycling in a coastal marine sediment, Aarhus bay, Denmark. Geochimica et Cosmochimica Acta, 58(23):5115-5129. https://doi.org/10.1016/0016-7037(94)90298-4

Torres, M.E., Hong, W.-L., Solomon, E.A., Milliken, K., Kim, J.-H., Sample, J.C., Teichert, B.M.A., and Wallmann, K., 2020. Silicate weathering in anoxic marine sediment as a requirement for authigenic carbonate burial. Earth-Science Reviews, 200:102960.

https://doi.org/10.1016/j.earscirev.2019.102960

Torres, M.E., Muratli, J.M., and Solomon, E.A., 2014. Data report: minor element concentrations in pore fluids from the CRISP-A transect drilled during Expedition 334. In Vannucchi, P., Ujiie, K., Stroncik, N., and the Expedition 334 Scientists, Proceedings of the Integrated Ocean Drilling Program, 334: Tokyo (Integrated Ocean Drilling Program Management International, Inc.). https://doi.org/10.2204/iodp.proc.334.201.2014

Tribovillard, N., Lyons, T.W., Riboulleau, A., and Bout-Roumazeilles, V., 2008. A possible capture of molybdenum during early diagenesis of dysoxic sediments. Bulletin de la Société Géologique de France, 179:3-12. https://doi.org/10.2113/gssgfbull.179.1.3

Turekian, K.K., 1968. Oceans: Englewood, New Jersey (Prentice-Hall).

Vannucchi, P., Galeotti, S., Clift, P.D., Ranero, C.R., and von Huene, R., 2004. Long-term subduction-erosion along the Guatemalan margin of the Middle America Trench. Geology, 32(7):617-620.

https://doi.org/10.1130/g20422.1 
Vannucchi, P., Sak, P.B., Morgan, J.P., Ohkushi, K., and Ujiie, K., 2013. Rapid pulses of uplift, subsidence, and subduction erosion offshore Central America; implications for building the rock record of convergent margins. Geology, 41(9):995. https://doi.org/10.1130/G34355.1

Wallmann, K., Aloisi, G., Haeckel, M., Tishchenko, P., Pavlova, G., Greinert, J., Kutterolf, S., and Eisenhauer, A., 2008. Silicate weathering in anoxic marine sediments. Geochimica et Cosmochimica Acta, 72(12):2895-2918. https://doi.org/10.1016/j.gca.2008.03.026

Welby, C.W., 1958. Occurrence of alkali metals in some Gulf of Mexico sediments. Journal of Sedimentary Research, 28(4):431-452. https://doi.org/10.1306/74d70830-2b21-11d7-8648000102c1865d 